\title{
PENINGKATAN KESADARAN HUKUM MASYARAKAT DESA WINDUJANTEN, KABUPATEN KUNINGAN, INDONESIA
}

\author{
Suwari Akhmaddhian, Erga Yuhandra dan Gios Adhyaksa \\ Fakultas Hukum, Universitas Kuningan, Kuningan, Indonesia \\ Email : suwari_akhmad@uniku.ac.id
}

\begin{abstract}
Devotion of Science and Technology for Society entitled Law Awareness Awareness Village Village Windujanten Kuningan designed by our team of executors aims to: (1). Increase knowledge of Windujanten Village community in the field of state administration law, agrarian law, contract law, inheritance law of Islam and corruption crime; 2). Improving legal skills such as good governance, registration of land certificates, contracting, calculating and distributing family inheritance and preventing criminal acts of corruption; 3). Increase public awareness in the field of law; 4). The creation of a peaceful and peaceful society. The Target of Community Service Science in general is the villagers of windujanten increased their legal awareness and the target in particular is 1). The villagers of windujanten are aware of their rights and obligations in the nation and state; 2). The villagers of windujanten have knowledge and skills in the field of state administrative law, agrarian law, contract law, inheritance law and corruption. 3). The creation of peaceful and peaceful community atmosphere for village government apparatus is better in running village governance. Method of Devotion of Science and Technology for Society to achieve that goal is training in the form of lecture, discussion, question and answer and practice of contract / agreement relating to field of law taught. The activities consist of 2 (two) participant groups consisting of 15 (fifteen) persons consisting of village apparatus starting from RT head, RW head, hamlet head, village apparatus and wider community from 2 (two) hamlets in 1 (one) village. The purpose of selecting 1 (one) village is to facilitate the early quality control and implementation of activities. The main activity is the participants who have attended the training is to exercise their rights and obligations in the state for example obedient paying taxes, carrying out the task of siskamling or patrolling and the creation of a peaceful atmosphere of peace and for the village government apparatus better in running good village governance so as to prevent corruption at the village level.
\end{abstract}

Keywords: Enhancement, Awareness, Law, Society.

\section{Abstrak}

Pengabdian Ipteks bagi Masyarakat $\left(\mathrm{I}_{b} \mathrm{M}\right)$ yang berjudul Peningkatan Kesadaran Hukum Masyarakat Desa Windujanten Kabupaten Kuningan dirancang oleh kami tim pelaksana bertujuan untuk: (1). Meningkatkan pengetahuan masyarakat Desa Windujanten dalam bidang hukum administrasi negara, hukum agraria, hukum kontrak, hukum waris islam dan tindak pidana korupsi; 2). Meningkatkan keterampilan dalam bidang hukum seperti tata kelola pepmeintahan yang baik, pendaftaran sertifikat tanah, membuat kontrak, perhitungan dan pembagian warisan keluarga dan pencegahan tindak pidana korupsi,; 3). Meningkatkan kesadaran masyarakat dalam bidang hukum; 4). Terciptanya kondisi masyaraakat yang aman dan tentram. Target Pengabdian Ipteks bagi Masyarakat $\left(\mathrm{I}_{b} \mathrm{M}\right)$ secara umum adalah masyarakat desa windujanten meningkat kesadaran hukumnya dan target secara khusus adalah 1). Masyarakat desa windujanten sadar akan hak dan kewajibannya dalam berbangsa dan negara; 2). Masyarakat desa windujanten memiliki pengetahuan dan keterampilan dalam bidang hukum administrasi negara, hukum agraria, hukum kontrak, hukum waris islam dan tindak pidana korupsi. 3).Terciptanya suasana masyarakat yang aman tentram dan untuk aparatur pemerintahan desa semakin baik dalam menjalankan tata kelola pemerintahan desa. Metode Pengabdian Ipteks bagi Masyarakat $\left(\mathrm{I}_{b} \mathrm{M}\right)$ untuk mencapai tujuan tersebut yaitu pelatihan berupa ceramah, diskusi, tanya jawab dan praktek perancangan kontrak/perjanjian yang berkaitan dengan bidang hukum yang diajarkan. Pelaksanaan kegiatan mencakup 2 (dua) kelompok peserta masing-masing berjumlah 15 (lima belas) orang yang terdiri dari aparatur desa mulai dari ketua RT, ketua RW, kepala dusun, perangkat desa dan masyarakat luas dari 2 (dua) dusun dalam 1 (satu) desa. Maksud pemilihan 1 (satu) desa adalah untuk mempermudah pengedalian kualitas awal dan pelaksanaan kegiatan. Kegiatan utama adalah peserta yang telah mengikuti pelatihan adalah menjalankan hak dan kewajibanya dalam bernegara 
contohnya taat membayar pajak, melaksanakan tugas sistem keamanan keliling atau ronda serta terciptanya suasana masyarakat yang aman tentram dan untuk aparatur pemerintahan desa semakin baik dalam menjalankan tata kelola pemerintahan desa yang baik sehingga dapat mencegah tindak pidana korupsi di tingkat desa.

Kata kunci : Peningkatan, Kesadaran, Hukum, Masyarakat.

\section{PENDAHULUAN}

Kabupaten Kuningan merupakan daerah pertanian berlokasi di kaki Gunung Ciremai dan memiliki sumber air melimpah, termasuk air tawar 620 mata air dan 43 sungai kecil dengan debit air total 8.352 liter / detik, dan karena itu penuh potensial agribisnis dan investasi dalam air berbasis perusahaan. Kabupaten Kuningan, adalah sebuah kabupaten di Provinsi Jawa Barat, Indonesia. Ibukotanya adalah Kuningan. Letak astronomis kabupaten ini di antara 108 $23^{\prime \prime}$ 108 $47^{\prime \prime}$ Bujur Timur dan 645" - 7¹3" Lintang Selatan. Kabupaten ini terletak di bagian timur Jawa Barat, berbatasan dengan Kabupaten Cirebon di utara, Kabupaten Brebes (Jawa Tengah) di timur, Kabupaten Ciamis di selatan, serta Kabupaten Majalengka di barat. Kabupaten Kuningan terdiri atas 32 kecamatan, yang dibagi lagi atas sejumlah 361 desa dan 15 kelurahan. Pusat pemerintahan di Kecamatan Kuningan. Bagian timur wilayah kabupaten ini adalah dataran rendah, sedang di bagian barat berupa pegunungan, dengan puncaknya Gunung Ceremai (3.076 m), gunung ini berada di perbatasan dengan Kabupaten Majalengka. Gunung Ceremai adalah gunung tertinggi di Jawa Barat. Mempunyai luas daerah yaitu 1.178,58 km² dan Menurut hasil Suseda Jabar tahun 2010, penduduk
Kab.Kuningan yang tersebar di 379 desa/kelurahan meliputi 32 kecamatan itu, seluruhnya tercatat 1.873 .528 jiwa. Desa windujanten merupakan desa yang terletak di kecamatan kadugede kabupaten kuningan.

Materi paling menarik dan perlu diwaspadai dari Undang-Undang No.6 Tahun 2014 tentang Desa atau UU Desa adalah tentang dana desa langsung dari pusat dan besar lura biasa, bagaimana sebenaranya, mari kita cermati. Dalam pasal Pasal 72 disebutkan ayat (1)Pendapatan Desa sebagaimana dimaksud dalam Pasal 71 ayat (2) bersumber dari:huruf (b.) alokasi Anggaran Pendapatan dan Belanja Negara; dan (d.) alokasi dana Desa yang merupakan bagian dari dana perimbangan yang diterima kabupaten/kota; Dilajutkan Pasal 72 disebutkan ayat (2) Alokasi anggaran sebagaimana dimaksud pada ayat (1) huruf $b$ bersumber dari Belanja Pusat dengan mengefektifkan program yang berbasis Desa secara merata dan berkeadilan, dan (4) Alokasi dana Desa sebagaimana dimaksud pada ayat (1) huruf d paling sedikit 10\% (sepuluh perseratus) dari dana perimbangan yang diterima kabupaten/kota dalam Anggaran Pendapatan dan Belanja Daerah setelah dikurangi Dana Alokasi Khusus. Dilanjut dengan penjelasan Pasal 72 ayat (1) huruf (b) Yang 
dimaksud dengan "Anggaran bersumber dari Anggaran Pendapatan dan Belanja Negara tersebut" adalah anggaran yang diperuntukkan bagi Desa dan DesaAdat yang ditransfer melalui Anggaran Pendapatan dan Belanja Daerah kabupaten/kota yang digunakan untuk membiayai penyelenggaran pemerintahan, pembangunan, serta pemberdayaan masyarakat, dan kemasyarakatan. Dan penjelasan Pasal 72 (2) Besaran alokasi anggaran yang peruntukkannya langsung ke Desa ditentukan $10 \%$ (sepuluh perseratus) dari dan di luar dana Transfer Daerah (on top) secara bertahap. Anggaran yang bersumber dari Anggaran Pendapatan dan Belanja Negara dihitung berdasarkan jumlah Desa dan dialokasikan dengan memperhatikan jumlah penduduk, angka kemiskinan, luas wilayah, dan tingkat kesulitan geografis dalam rangka meningkatkan kesejahteraan dan pemerataan pembangunan Desa. Dalam pasal ini maka yang harus dipahami adalah :

1. Pengalokasian dana untuk desa adalah dalam hal keperluan mengefektifkan program yang berbasis Desa secara merata danberkeadilan, jadi program lembaga atau kementerian yang sekarang sudah berjalana tau telah berjalan yang berbasis desa, bisa jadi kemudian dihentikan pada saatdana desa mulai dikucurkan;

2. Ada dana peruntukan penyelenggaraan pemerintahan seperti penghasilan kepala desa dan perangat desa tiap bulan;
3. Alokasi dana Desa, adalah mendasar pada perhitungan transfer daerah;
4. Alokasi Dana Desa diberikan secara bertahap.

Untuk ilustrasi kita ambil contoh salah satu kabupaten di Provinis Jawa Barat yaitu Kabupaten Bogor berdasar data pada tahun 2013 yaitu : Dana Alokasi Umum Rp. 1,887,770,112,500, Dana Bagi Hasil Rp. 192,162,259,652 dan Jumlah Rp. 2,079,932,372,152 dan perhitungan $10 \%$ adalah $\mathrm{Rp}$. 207,993,237,215 dari Jumlah Desa yang ada yaitu 414 jadi Alokasi Dana Desa rata-rata dari APBN adalah Rp. 502,399,124/Desa.

Kebijakan pemerintah menetapkan arah pengelolaan pemerintahan menuju tata kelola pemerintahan yang baik (good governance) dan reformasi birokrasi, merupakan pilihan yang rasional (rationalchoice). Salah satu agenda besar menuju good governance dan reformasi birokrasi adalah peningkatan profesionalisme aparatur pemerintah, baik di tingkat pusa tmaupun di tingkat desa. Dalam rangka peningkatan profesionalisme aparatur pemerintah desa, perlu diperhatikan: pengembangan kapasitas aparatur pemerintah desa dengan prioritas peningkatan kemampuan dalam pelayanan publikseperti kebutuhan dasar masyarakat, keamanan dan kemampuan di dalam menghadapi bencana, kemampuan penyiapan rencana strategis pengembangan ekonomi desa,kemampuan 
pengelolaan keuangan desa, dan pengelolaan kelestarian lingkungan hidup. Untuk itu, aparatur pemerintah desa patutmemahami peran strategisnya agar belajar mendalami, menggali serta mengkajiberbagai permasalahan dan tantangan pelaksanaan good governance dan reformasi birokrasi ke depan, untuk dapat diterapkan secara optimal di lingkungan kerja masing-masing. Kualitas tata kelola yang mumpuni perlu ditunjang dengan kapasitas aparatur desa yaitu melalui pengingkatan kemampuan dan keterampilan ilmu pemerintahan dan khususnya adalah pengetahuan dan ketarampilan dalam bidang hukum sehingga dalam menjalani pemerintahan desa sesuai dengan peraturan perundang-undangan yang berlaku oleh karena itu IbM ini bermaksud untuk meningkatkan kesadaran hukum masyarakat khususnya aparatur desa di desa windujanten kabupaten kuningan provinsi jawa barat.

\section{METODE PELAKSANAAN}

Sebagaimana telah dijelaskan pada Bab.I, masalah utama peserta adalah pnegetahuan dan keterampilan bidang hukum untuk menghadapi globalisasi, pelayanan publik dan transparansi tata kelola pemerintahan desa. Hal ini menunjukan yang menunjukan bahwa pengetahuan masyarakat terkait bidang hukum masih kurang memadai dalam menghadapi tantangan perubahan jaman yang terus berkembang dan berubah. Disamping itu, kondisi mitra bersedia memberikan bantuan dalam bentuk layanan fisik yaitu berupa bantuan tenaga. Oleh karena itu, untuk mengatasi masalah tersebut disepakati dilakukan kegiatan yang berupa memberi pengetahuan serta keterampilan dalam pelatihan yang diberikan kepada peserta $\mathrm{Ib}_{\mathrm{b}} \mathrm{M}$. Metode penerapan kegiatan yang dianggap tepat menurut pengusul yaitu, peningkatan kesadaran hukum masyarakat desa windujanten kecamatan kadugede kabupaten kuningan semakin meningkat. Adapun langkah-langkah pelaksanaan kegiatn IbM yaitu berupa :

1. Pelatihan

a. Pelatihan diikuti oleh 30 (tiga puluh) orang yang terdiri dari perangkat desa, kepala dusun, ketua RT, ketua RW dan masyarakat lainnya yang berasal dari 2 (dua) kelompok masing-masing terdiri dari 15 (lima belas) orang yang berasal dari 2 (dua) dusun dalam 1 (satu) desa;

b. Untuk membuka wawasan tentang hukum, model yang digunakan berupa ceramah dan diskusi mengenai bidang bidang hukum adminstrasi negara, hukum agraria, hukum kontrak/perjanjian, hukum waris islam dan tindak pidana korupsi. dan;

c. Praktek yaitu untuk memberikan keterampilan dalam menciptakan tata kelola pemerintahan yang baik sesuai 
dengan asas-asas pemerintahan yang baik, tata cara pendaftaran sertifikat tanah, membuat perjanjian/kontrak yang kaitannya dengan usaha peserta, perhitungan dan pembagian warisan keluarga, dan pencegahan tindak pidana korupsi.

2. Tim pelatihan terdiri dari tim pengusul proposal dan beberapa orang dari masyarakat dan instansi pemerintah yang dianggap mampu menjadi instruktur dalam memberikan pengetahuan dan keterampilan dalam kegiatan $\mathrm{IbM}$.

\section{HASIL DAN PEMBAHASAN}

Hasil yang sudah dicapai dalam pengabdian Iptkes bagi Masyarakat (IbM) adalah:

1. Kegiatan koordinasi sekaligus survey sekolah pelaksanaan kegiatan pengabdian.

Kegiatan ini merupakan koordinasi awal dengan pemerintah setempat, dalam hal ini kecamatan Kadugede. Setelah mendapat persetujuan dari kecamatan Kadugede, selanjutnya melakukan koordinasi dengan Kepala Dusun Wage dan Kepala Dusun Puhun Desa Windujanten Kecamatan Kadugede. Melalui wawancara dengan kepala dusun diperoleh informasi tentang pemahaman perlunya perangkat desa serta masyarakat desa windujanten tentang hukum yang sedang berkembang. Sehingga perlu adanya peningkatan kapasitas masyarakat khususnya dalam bidang hukum seperti hukum seperti tata kelola pepmeintahan yang baik, pendaftaran sertifikat tanah, membuat kontrak, perhitungan dan pembagian warisan keluarga dan pencegahan tindak pidana korupsi. Hasil koordinasi dengan pimpinan desa, disepakati kegiatan dilaksanakandi Aula Desa Windujanten dengan fasilitas ruangan, sound system dan LCD yang dianggap sudah memenuhi untuk melaksanakan pelatihan.

2. Pelaksanaan Pelatihan

Penyuluhan hukun dan Pelatihan dilaksanakan selama 2 (dua) hari bertempat di Aula Desa Windujanten.

3. Refleksi Hasil Pelatihan

Selama proses pelatihan, tim pelaksana kegiatan pengabdian melakukan pemantauan kepada peserta pelatihan sekaligus melakukan wawancara terhadap materi, metode dan instruktur dalam kegiatan ini. Secara umum peserta mengatakan pelatihan ini sangat baik dan materi yang diberikan merupakan materi yang sangat dibutuhkan dalam meningkatkan kapasitas bidang hukum masyarakat desa sedangkan instrukturnya sangat berkompoten.

Tahapan pelaksanaan pengabdian yang sudah dilakukan sampai saat ini adalah pada tahapan pelatihan perangkat desa/masyarakat/peserta dalam peningkatan pemahaman hukum dan pembuatan perjanjian 
serta perhitungan waris. Hasil yang diharapkan pada tahap ini adalah perangkat desa/masyarakat/peserta mengenal bidang-bidang hukum yang ada di indonesia serta dapat mempunyai kemampuan dalam membuat dokumen hukum seperti perjanjian atau cara menghitung waris. Pada tahapan selanjutnya adalah melakukan pendampingan bagi perangkat desa/masyarakat/peserta dalam membuat berbagai dokumen hukum seperti surat perjanjian dan menghitung pembagian waris serta pendampingan dalam pembuatan peraturan desa (perdes).

\section{SIMPULAN dan SARAN}

Berdasarkan uraian di atas maka penulis Kegiatan pengabdian Ipteks bagi Masyarakat (IbM) sudah dilakukan berupa penyuluhan hukum serta pelatihan pembuatan dokumen hukum seperti surat perjanjian dan perhitungan waris. Pelatihan diawali dengan pengenalan berbagi bidang hukum yang ada di indonesia, kemudian dilanjutkan dengan peningkatan pengetahuan melalui penyuluhan hukum dan pelatihan. Dari hasil diskusi dengan kepala desa dan perangkat desa, mulai dari awal koordinasi dan selama pelaksanaan pengabdian, mereka sangat mengharapkan penyuluhan hukum serta pelatihan-pelatihan seperti pembuatan dokumen hukum. Namun kegiatan ini diharapkan tidak berakhir pada kegiatan pengabdian, tetapi bisa dibentuk kerjasama dalam pendampingan yang berkaitan dengan hukum misalnya adalah pendampingan perkara masyarakat tidak mampu, penyuluhan rutin kepada masyarakat desa windujanten serta pendampinga Usaha Kecil dalam meningkatkan kaspasitasnya terutama kaitannya dengan perizinan usaha.

\section{DAFTAR PUSTAKA}

Hartanti, Evi, 2005. Tindak Pidana Korupsi. Sinar Grafika : Jakarta.

Marpaung, Leden, S.H., 1992. Tindak Pidana Korupsi : Masalah dan Pemecahannya Bagian kedua. Sinar Grafika : Jakarta.

Sutoro Eko, Februari 2014 Desa membangun Indonesia Cetakan pertama Forum Pengembangan Pembaharuan Desa (FPPD) Laman setkab.go.id, Minggu

Presiden Bentuk Komite Persiapan Pelaksanaan Masyarakat Ekonomi ASEAN

Sutardjo , Tantangan Desa Menuju Masyarakat Ekonomi Asean (MEA) 2015

Suryokoco/uu-desa-butuhpeningkatan-kapasitas-aparat-desa suryokoco/uu-desa-butuh-

peningkatan-kapasitas-aparat-desa

Suwari Akhmaddhian dan Anthon

Fathanudien. Partisipasi Masyarakat dalam Mewujudkan Kuningan sebagai Kabupaten Konservasi (Studi di Kabupaten Kuningan). Jurnal UNIFIKASI Vol. 2 (1). 2015. DOI: https://doi.org/10.25134/unifikas i.v2i1.26

Yuhandra, Erga. Kewenangan BPD (Badan Permusyawaratan Desa) 
Empowerment : Jurnal Pengabdian Masyarakat, e-ISSN 2598-2052

Vol. 01 Nomor 01 Januari 2018

Dalam Menjalankan Fungsi

Legislasi (Sebuah Telaah Sosiologis

Proses Pembentukan Perdes Di

Desa Karamatwangi Kec.

Garawangi Kab. Kuningan).

UNIFIKASI: Jurnal Ilmu Hukum.

Volume 3 Nomor 2. 2016.

Fakultas Hukum Universitas

Kuningan.

DOI: https://doi.org/10.25134/uni

fikasi.v4i1.477

Tarsim dan Erga Yuhandra, Implementasi Kewenangan Badan

Permusyawaratan Desa (BPD)

Dalam Menjalankan Fungsi

Pengawasan Terhadap Pemerintah

Desa (Studi Di Kabupaten

Kuningan), UNIFIKASI: Jurnal

Ilmu Hukum. Volume 5 Nomor

1. 2018. Fakultas Hukum

Universitas Kuningan. DOI:

https://doi.org/10.25134/unifikasi

. $\mathrm{v} 5 \mathrm{i} 1.759$

http://www.republika.co.id/berita/nasi

onal/jawa-timur/13/11/25/mwspqv-

parah-ratusan-kepala-desa-

diduga-korupsi-raskin

http://regional.kompas.com/read/2015/

01/21/15165221/Tiga.Kades.di.Ken

dal.Jadi.Tersangka.Korupsi.Dana.

Desa

http://daerah.sindonews.com/read/885

539/21/3-kepala-desa-di-

majalengka-korupsi-dana-

bantuan-provinsi

http://dhitaanderesoon.blogspot.com/2

010/02/penyebab-munculnya-

korupsi.html 